\title{
Leisingera methylohalidivorans gen. nov., sp. nov., a marine methylotroph that grows on methyl bromide
}

${ }^{1}$ Cook College, Rutgers University, New Brunswick, NJ 08901-8520, USA

${ }^{2}$ Cooperative Institute for Marine and Atmospheric Studies, Rosenstiel School of Marine and

Atmospheric Sciences, University of Miami, Miami, FL 33149, USA

${ }^{3}$ Department of Biological Sciences, University of Warwick, Coventry CV4 7AL, UK

${ }^{4}$ US Geological Survey, 345 Middlefield Rd, MS 480, Menlo Park, CA 94025 USA

\author{
Jeffra K. Schaefer, ${ }^{1}$ Kelly D. Goodwin, ${ }^{2}$ Ian R. McDonald, ${ }^{3}$ \\ J. Colin Murrell ${ }^{3}$ and Ronald S. Oremland ${ }^{4}$
}

Author for correspondence: Ronald S. Oremland. Tel: +1 650329 4482. Fax: + 16503294463. e-mail: roremlan@usgs.gov

\begin{abstract}
A marine methylotroph, designated strain $\mathrm{MB2}^{\top}$, was isolated for its ability to grow on methyl bromide as a sole carbon and energy source. Methyl chloride and methyl iodide also supported growth, as did methionine and glycine betaine. A limited amount of growth was observed with dimethyl sulfide. Growth was also noted with unidentified components of the complex media marine broth 2216, yeast extract and Casamino acids. No growth was observed on methylated amines, methanol, formate, acetate, glucose or a variety of other substrates. Growth on methyl bromide and methyl iodide resulted in their oxidation to $\mathrm{CO}_{2}$ with stoichiometric release of bromide and iodide, respectively. Strain $\mathrm{MB2}^{\top}$ exhibited growth optima at $\mathrm{NaCl}$ and $\mathrm{Mg}^{2+}$ concentrations similar to that of seawater. Phylogenetic analysis of the $16 S$ rDNA sequence placed this strain in the $\alpha$-Proteobacteria in proximity to the genera Ruegeria and Roseobacter. It is proposed that strain MB2 $^{\top}$ ( $=$ ATCC BAA-92 $^{\top}=$ DSM $14336^{\top}$ ) be designated Leisingera methylohalidivorans gen. nov., sp. nov.
\end{abstract}

Keywords: methyl halides, methylotrophic bacterium, marine, Ruegeria, Roseobacter

\section{INTRODUCTION}

Release of methyl bromide (MeBr) and methyl chloride $(\mathrm{MeCl})$ into the atmosphere leads to transport of bromine and chlorine atoms to the stratosphere, which contributes to the catalytic destruction of ozone (Mellouki et al., 1992). There have been several reports of microbiological degradation of methyl halides in recent years, which suggest the importance of bacteria in the global biogeochemical cycle of methyl halides. $\mathrm{MeBr}$ can be degraded by natural populations of bacteria in agricultural and forest soils (Hines et al., 1998; Miller et al., 1997; Varner et al., 1999), in seawater (Goodwin et al., 1998; King \& Saltzman, 1997; Tokarczyk \& Saltzman, 2001), and in freshwater, estuarine and hypersaline/alkaline aquatic

Abbreviations: AODC, acridine orange direct counts; DMS, dimethy sulfide; $\mathrm{MeBr}$, methyl bromide; $\mathrm{MeCl}$, methyl chloride; Mel, methyl iodide. Published online ahead of print on 18 February 2002 as DOI 10.1099/ijs.0.01960-0.

The GenBank accession number for the $16 \mathrm{~S}$ rRNA sequence of strain $\mathrm{MB}^{\top}{ }^{\top}$ is AY005463. systems (Connell et al., 1997; Goodwin et al., 1998). Methanotrophs and ammonia oxidizers co-oxidize methyl halides via their respective mono-oxygenases (Duddleston et al., 2000; Keener \& Arp, 1993; Oremland et al., 1994). However, neither methanotrophs nor ammonia oxidizers play a significant role in the oxidation of $\mathrm{MeBr}$ in coastal waters (Goodwin et al., 1998).

Marine isolates able to grow on methyl halides have not previously been described in detail, but several terrestrial bacteria are now known. These include several facultative methylotrophs in the genera Hyphomicrobium and Methylobacterium (Doronina \& Trotsenko, 1997; McDonald et al., 2001). Strains CC495 (Coulter et al., 1999) and IMB-1 (Connell Hancock et al., 1998) can also grow on methyl halides. Of all of the above listed bacteria, only strain IMB-1 was isolated using $\mathrm{MeBr}$ as the sole carbon source; the others were isolated with $\mathrm{MeCl}$. Hoeft et al. (2000) reported isolation of several marine methylotrophs capable of co-oxidizing $\mathrm{MeBr}$ during growth on dimethyl sulfide (DMS), and one strain was reported able to grow on $\mathrm{MeBr}$. 
The oceans act as a net biological and chemical sink for $\mathrm{MeBr}$ (Yvon \& Butler, 1996; Yvon-Lewis \& Butler, 1997). However, relatively little is known about the actual organisms and the enzymes involved in the degradation of methyl halides in the oceans. In this paper, the isolation and characterization of a marine methylotroph able to grow on methyl halides as a sole carbon and energy source are reported. This organism, strain $\mathrm{MB}^{\mathrm{T}}$, is the first species isolated from seawater using $\mathrm{MeBr}$ as its sole growth substrate. Based on its 16S rDNA gene sequence alignment and DNA-DNA hybridization studies, this strain is proposed as a new member of a new genus of the $\alpha$-Proteobacteria, Leisingera methylohalidivorans gen. nov., sp. nov.

\section{METHODS}

Isolation. An MeBr-degrading enrichment culture was established from seawater collected from a tide pool off the coast of central California as described by Goodwin et al. (1998). The enrichment (and the subsequent pure culture) was maintained in liquid culture for $>3$ years with $\mathrm{MeBr}$ as its sole source of carbon and energy. Isolation of a pure culture was achieved by plating on a mineral salts medium containing $0.5 \%(\mathrm{w} / \mathrm{v})$ Phytagel (Sigma). Plates were incubated in a gas-tight container containing $100 \mu \mathrm{mol} \mathrm{MeBr} \mathrm{m}^{-1}$ in the gas phase $(0.34 \%, \mathrm{v} / \mathrm{v})$. The medium (MAMS) was adapted from Thompson et al. (1995) and contained $\left(\mathrm{g} \mathrm{l}^{-1}\right): \mathrm{NaCl}(16),\left(\mathrm{NH}_{4}\right)_{2} \mathrm{SO}_{4}(1 \cdot 0), \mathrm{MgSO}_{4} \cdot 7 \mathrm{H}_{2} \mathrm{O}(1 \cdot 0)$, $\mathrm{CaCl}_{2} \cdot 2 \mathrm{H}_{2} \mathrm{O}(0 \cdot 2), \mathrm{FeSO}_{4} \cdot 7 \mathrm{H}_{2} \mathrm{O}(0 \cdot 002), \mathrm{Na}_{2} \mathrm{MoO}_{4} \cdot 2 \mathrm{H}_{2} \mathrm{O}$ (0.002), $\mathrm{Na}_{2} \mathrm{WO}_{4}(0 \cdot 003), \mathrm{KH}_{2} \mathrm{PO}_{4}(0 \cdot 36), \mathrm{K}_{2} \mathrm{HPO}_{4}(2 \cdot 34)$ and $1.0 \mathrm{ml} \mathrm{SL}-10$ trace metals (Widdel et al., 1983). The phosphates were added after autoclaving from sterile stock solutions. The final $\mathrm{pH}$ of the medium was $6 \cdot 9-7 \cdot 1$.

The culture was streaked for purity four times prior to transferring back into liquid mineral salts medium having the same composition as given above. Liquid cultures were maintained in Balch tubes, crimp-sealed with an air gas phase $(16 \mathrm{ml})$ and $10 \mathrm{ml}$ MAMS medium. Liquid cultures typically received three additions of $\mathrm{MeBr}$, each about $\sim 0.63 \%$ (v/v) gas phase, which is equivalent to a dissolved concentration of $\sim 300 \mu \mathrm{M}$ per addition (see below) prior to transfer to fresh medium. This course of pulsed $\mathrm{MeBr}$ injection was followed to prevent incubation of cultures with toxic levels of $\mathrm{MeBr}$, which would preclude growth (Miller et al., 1997; Connell Hancock et al., 1998). Following isolation, strain $\mathrm{MB}^{\mathrm{T}}$ could be successfully grown on marine agar 2216 (Difco) or MAMS containing $1.5 \%$ agar and yeast extract $(0.5 \%, \mathrm{w} / \mathrm{v})$.

Growth experiments. Potential growth substrates were added to strain $\mathrm{MB}^{\mathrm{T}}$ in liquid MAMS medium either with or without a vitamin mix that included $\mathrm{B}_{12}\left(1 \mathrm{mll}^{-1}\right)$ (Pfennig, 1978). Cultures were grown in Balch tubes (see above) or in $159 \mathrm{ml}$ serum vials containing $50 \mathrm{ml}$ media, each of which was sealed with butyl rubber stoppers and incubated at $21{ }^{\circ} \mathrm{C}$ on a rotary shaker at 200 r.p.m. Cultures were grown with an air: liquid ratio of $\sim 2: 1$ to reduce oxygen limitation. This was effective because no oxygen limitation was noted when comparing growth on yeast extract in sealed Balch tubes with growth obtained in cotton-stoppered conical flasks (data not shown). $\mathrm{MeBr}$ and $\mathrm{MeCl}$ were added to sealed cultures as a gas, whereas methyl iodide (MeI) was added to cultures from aqueous solutions in closed vials lacking any headspace.
Growth was monitored by measuring changes in $\mathrm{OD}_{680}$ on a Spectronic 20 spectrophotometer or by acridine orange direct counts (AODC) (Hobbie et al., 1977). Specific growth rates $(\mu)$ were determined by a least-squares linear fit to the following formula: $\mu=\ln \left(N / N_{0}\right) / t$ where $N$ is the number of cells at time $t$ (in h) and $N_{0}$ is the number of cells at $t=0$. Growth on the following compounds was measured by AODC: acetate, cysteine, DMS, dimethylamine, methanesulfonic acid, methionine, methyl halides and trimethylamine. Growth on all other substrates was tested by measuring $\mathrm{OD}_{680}$. Due to the pleomorphic nature of the cells when grown on yeast extract and glycine betaine, accurate measurements of direct cell counts were not possible for these substrates.

Optimal growth conditions (salinity, $\mathrm{pH}$ and temperature) were determined in Balch tubes containing MAMS media supplemented with $0.2 \%(\mathrm{w} / \mathrm{v})$ yeast extract. The magnesium requirements of the culture were tested by varying the $\mathrm{MgSO}_{4}$ concentration (0.01-15 $\left.\mathrm{g} \mathrm{l}^{-1}\right)$ and compared with growth in which $\mathrm{Na}_{2} \mathrm{SO}_{4}$ was added in lieu of $\mathrm{MgSO}_{4}$. Variations in $\mathrm{pH}$ were achieved by adjusting the medium with acid or base prior to autoclaving and by verifying the $\mathrm{pH}$ after autoclaving. Magnesium and calcium salts were added as sterile solutions after cooling. Some precipitation was noticeable in media with $\mathrm{pH} \geqslant 8$. For the purpose of making physiological comparisons, strain IMB-1 (= ATCC 202197), an MeBr-oxidizing terrestrial bacterium (Connell Hancock et al., 1998; Miller et al., 1997; Schaefer \& Oremland, 1999), was subjected to the same growth conditions of temperature, $\mathrm{pH}$ and salinity.

Washed cell experiments. Cells were harvested in late exponential phase, washed twice with MAMS medium lacking nitrogen, trace metals and carbon, and then resuspended in this adapted medium (Connell Hancock et al., 1998). To test if $\mathrm{MeBr}$ oxidation was constitutive or inducible, strain $\mathrm{MB} 2^{\mathrm{T}}$ was subcultured five times on MAMS medium with hydrolysed casein as the carbon and energy source. Washed cell suspensions $(20 \mathrm{ml})$ were dispensed into $57 \mathrm{ml}$ serum bottles, stoppered and crimp-sealed. Chloramphenicol $\left(20 \mu \mathrm{g} \mathrm{ml}^{-1}\right)$ was added to half the bottles just prior to the addition of $\mathrm{MeBr}$.

Incubation experiments with ${ }^{14} \mathrm{C}-\mathrm{MeBr}$ were conducted using washed suspensions of methionine-grown cells. Cells $(3 \mathrm{ml})$ were dispensed into $13 \mathrm{ml}$ serum bottles, stoppered and crimp-sealed with an air atmosphere and injected with $0.55 \mu \mathrm{Ci}\left(2.04 \times 10^{4} \mathrm{~Bq}\right){ }^{14} \mathrm{C}-\mathrm{MeBr}$ (specific activity, 52.6 $\mathrm{mCi} \mathrm{mmol}{ }^{-1}$ or $195 \times 10^{7} \mathrm{~Bq} \mathrm{mmol}{ }^{-1}$; purity $=99.9 \%$; NEN). The reaction was stopped by the injection of $0 \cdot 25 \mathrm{ml} 6 \mathrm{M} \mathrm{HCl}$, also liberating ${ }^{14} \mathrm{CO}_{2}$ into the gas phase.

Analytical techniques. Headspace methyl halide concentrations were determined by GC (Miller et al., 1997). Unless otherwise noted, methyl halide concentrations in the aqueous phase are reported. Aqueous concentrations were determined using the following dimensionless Henry's coefficients: MeBr, 0.24 (DeBruyn \& Saltzman, 1997); $\mathrm{MeCl}, 0.45$ (Schauffler et al., 1998); and MeI, 0.23 (HunterSmith et al., 1983). Bromide and iodide in solution were determined by ion chromatography (Connell Hancock et al., 1998). The concentration of ${ }^{14} \mathrm{CO}_{2}$ in acidified bottles was measured by $\mathrm{GC}$ in series with gas proportional counting (Culbertson et al., 1981).

Morphological and phenotypic analyses. Samples for scanning electron microscopy (SEM) (Hitachi S-4700) were prepared according to the procedure employed by Smith et al. (1985). Cells were tested for catalase via the SpotTest kit (Difco). Sensitivity to penicillin $\mathrm{G}\left(50 \mu \mathrm{g} \mathrm{ml}^{-1}\right)$ was 
assessed by following $\mathrm{MeBr}(\sim 250 \mu \mathrm{M})$ degradation and visual turbidity in stoppered Balch tubes containing $10 \mathrm{ml}$ fresh MAMS medium and a $0.5 \mathrm{ml}$ inoculum. This culture was monitored for 1 month and compared to an otherwise identical inoculated control tube that lacked penicillin $\mathrm{G}$.

Phylogenetic analysis. DNA of strain $\mathrm{MB}^{\mathrm{T}}$ was extracted (Marmur, 1961) and the 16S rRNA genes were PCRamplified with primers $f 27$ and r1492 (Lane, 1991). PCR products were checked on $1 \%(\mathrm{w} / \mathrm{v})$ agarose gels and fragments of the correct size were cloned using the TOPO TA cloning kit (Invitrogen). Small-scale preparations of plasmid DNA (Saunders \& Burke, 1990) from 20 clones were screened by randomly amplified polymorphic DNA analysis to ensure the purity of the DNA prior to sequencing. DNA sequencing reactions (Lane, 1991) were carried out from DNA of two clones by cycle sequencing using the ABI PRISM Dye Terminator kit (PE Applied Biosystems). The resulting sequences from the two clones were identical. The complete $16 \mathrm{~S}$ rRNA sequence (1431 bp) was aligned, using the ARB program for sequence alignment (Strunk et al., 2000), to representative organisms from the same and related genera of bacteria. Phylogenetic position was determined using the DNADIST, DNAML, DNAPARS and SEQBOOT programs of the PHYLIP package and supported by bootstrap values (Felsenstein, 1993). Phylogenetic dendrograms were constructed from distance data using the Fitch-Margoliash method and the dendrograms were drawn using the TREEVIEW program V1.5 (Page, 1996).

DNA-DNA hybridization. Genomic DNA from strain MB2 was compared to reference strains, Ruegeria algicola strain $\mathrm{FF}^{\mathrm{T}}\left(=\mathrm{ATCC} 51440^{\mathrm{T}}\right)$ and Roseobacter gallaeciensis strain BS107 ${ }^{\mathrm{T}}$ (= ATCC $\left.700871^{\mathrm{T}}\right)$ by DNA-DNA hybridization assays following Johnson (1994). DNA was extracted as mentioned previously (Marmur, 1961) and sonicated to give fragments $<1 \mathrm{~kb}$. DNA from strain $\mathrm{MB} 2^{\mathrm{T}}$ was labelled with [methyl- $\left.{ }^{3} \mathrm{H}\right]$-dTT (NEN DuPont) using the Nick Translation kit (Gibco-BRL) and separated from unreacted [methyl $\left.-{ }^{3} \mathrm{H}\right]-$ dTT by centrifugation using Nu-Clean D50 spin columns (Shelton Scientific). Hybridization was carried out at $62^{\circ} \mathrm{C}$ for $24 \mathrm{~h}$ and the S1 nuclease method was used to digest unhybridized DNA. Reassociated DNA was collected on $\mathrm{GF} / \mathrm{F}$ filters following acid precipitation with $\mathrm{HCl}-\mathrm{PP}$ ( $1 \mathrm{M} \mathrm{HCl} ; 1 \%$, w/v, $\mathrm{Na}_{4} \mathrm{P}_{2} \mathrm{O}_{7} .7 \mathrm{H}_{2} \mathrm{O} ; 1 \%$, w/v, $\mathrm{NaH}_{2} \mathrm{PO}_{4}$ ). Filters were counted using a liquid scintillation spectrophotometer. Each hybridization reaction was done in triplicate. The percentage similarity between strain $\mathrm{MB}^{\mathrm{T}}$ and the two reference strains was based on a relative scale. Salmon sperm DNA was used to define $0 \%$ similarity and unlabelled DNA from strain MB2 ${ }^{\mathrm{T}}$ was used to define $100 \%$ similarity. The $\mathrm{G}+\mathrm{C}$ content was determined at Deutsche Sammlung von Mikroorganismen und Zellkulturen.

\section{RESULTS AND DISCUSSION}

\section{Morphology}

Strain $\mathrm{MB}^{\mathrm{T}}$ exhibited pleomorphism, depending on the growth substrate. The strain formed single or paired rods $(1 \cdot 1-1.4 \times 0.4-0.5 \mu \mathrm{m})$ (Fig. 1, top) when grown with methyl halides, methionine or DMS on mineral medium. When cultured with yeast extract or glycine betaine, the rods became enlarged and elongated $(2 \cdot 4-8.2 \times 0.7-0.8 \mu \mathrm{m})$ (Fig. 1, bottom). Yeastgrown cell lines returned to mineral salts medium with
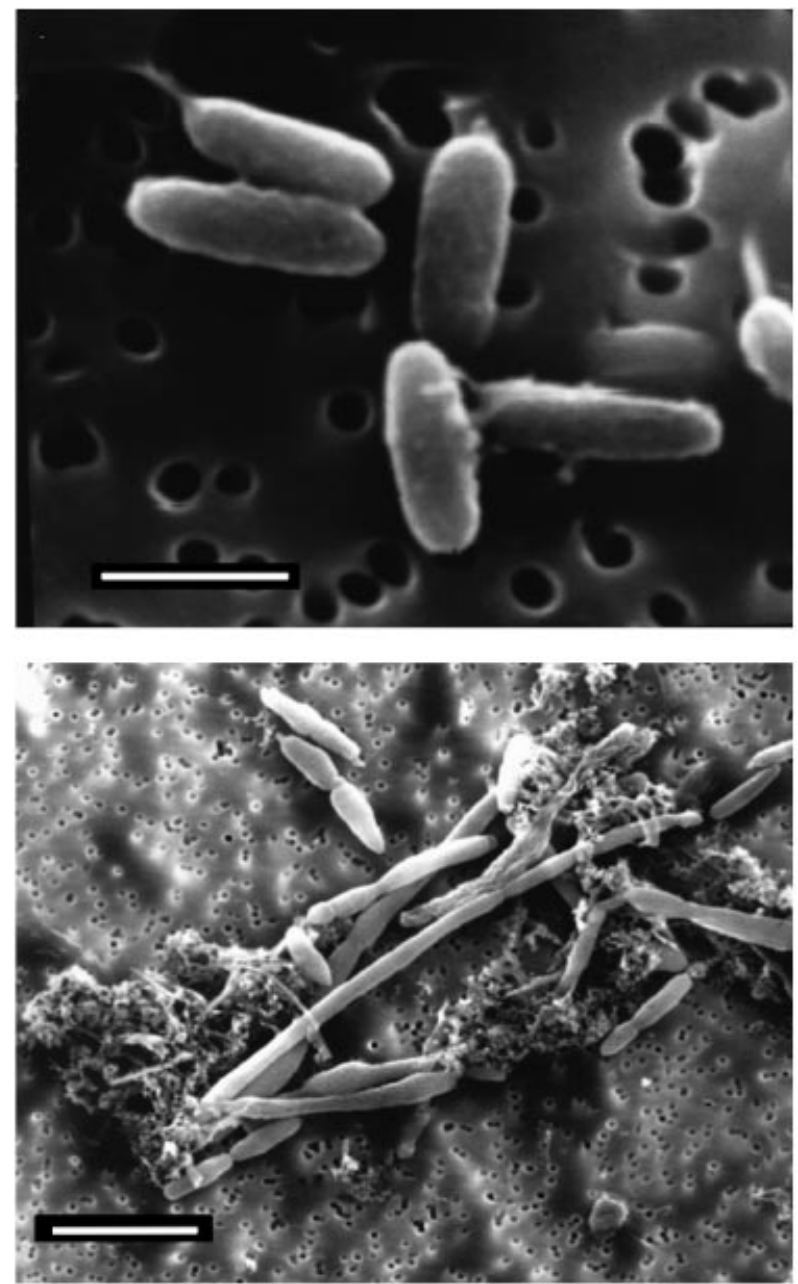

Fig. 1. $\mathrm{SEMs}$ of strain $\mathrm{MB} 2^{\top}$ grown on $\mathrm{MeBr}$ (top; bar, $1 \mu \mathrm{m}$ ) and yeast extract (bottom; bar, $4 \mu \mathrm{m}$ ).

$\mathrm{MeBr}$ as the substrate re-established their original form. In contrast, cells grown on marine broth showed the standard rod morphology.

Colonies were non-pigmented, smooth, with an entire edge when grown on solid media regardless of carbon source. When grown on $\mathrm{MeBr}$ on solid media, colony diameter was $<1 \mathrm{~mm}$ within 2-4 days; however, when grown on solid media with yeast extract or marine agar, the diameter was $\sim 2-3 \mathrm{~mm}$ within 2-3 days. Cells stained Gram-negative and they displayed obvious motility when viewed by phase-contrast microscopy. Additional phenotypic characteristics of this strain are given in Table 1.

\section{Growth substrates}

Strain $\mathrm{MB}^{\mathrm{T}}$ had a limited substrate range, being able to grow only on the following defined substrates out of the variety tested ( $\mu$, substrate concentration): glycine betaine $\left(0.24 \mathrm{~h}^{-1}, 1 \mathrm{mM}\right)$, methionine $\left(0.09 \mathrm{~h}^{-1}\right.$, $10 \mathrm{mM}), \operatorname{MeBr}\left(0.07 \mathrm{~h}^{-1}, 0.24 \mathrm{mM}\right), \mathrm{MeCl}\left(0.05 \mathrm{~h}^{-1}\right.$, 
Table 1. Comparison of Leisingera methylohalidivorans $\mathrm{MB}^{\top}$ to its nearest relatives within the $\alpha$-Proteobacteria

All three type strains are positive for catalase and oxidase. +, Positive reaction; - , negative reaction. For growth substrates: - , $\mathrm{OD}_{680}<0.01 ;+, \mathrm{OD}_{680} \geqslant 0.02 ;++, \mathrm{OD}_{680} \geqslant 0 \cdot 1 ;+++, \mathrm{OD}_{680}>0 \cdot 5 ; \mathrm{ND}$, not determined.

\begin{tabular}{|c|c|c|c|}
\hline Characteristic & $\begin{array}{c}\text { Leisingera } \\
\text { methylohalidivorans } \mathrm{MB2}^{\mathrm{T}}\end{array}$ & Ruegeria algicola $\mathrm{FF3}^{\mathrm{T} *}$ & $\begin{array}{c}\text { Roseobacter gallaeciensis } \\
{\mathrm{BS} 107^{\mathrm{T}} \uparrow}^{\text {Re }}\end{array}$ \\
\hline Morphology & Rods or ovoid rods & Ovoid rods & Ovoid rods \\
\hline Starch hydrolysis & + & + & - \\
\hline Salinity range $(\%)$ & $15-65$ & $6-120$ & $6-120$ \\
\hline Temperature optimum $\left({ }^{\circ} \mathrm{C}\right)$ & 27 & $25-30$ & $23-27$ \\
\hline $\mathrm{pH}$ optimum & $7 \cdot 7$ & $7 \cdot 5$ & $7 \cdot 0$ \\
\hline \multicolumn{4}{|l|}{ Vitamin requirement: } \\
\hline Thiamin & - & + & + \\
\hline Biotin & - & + & - \\
\hline Penicillin $G$ resistance & - & - & + \\
\hline Pigment & None & Beige & Brownish, diffusible \\
\hline $\mathrm{G}+\mathrm{C}$ content $(\mathrm{mol} \%)$ & $60 \cdot 5$ & 60 & $57 \cdot 6-58 \cdot 0$ \\
\hline \multicolumn{4}{|l|}{ Substrates for growth $(5 \mathrm{mM})$ : } \\
\hline Acetate & - & + & + \\
\hline Lactate & - & ND & ND \\
\hline Methanol (1-5 mM) & - & - & - \\
\hline Malate & - & + & ND \\
\hline Pyruvate & - & + & + \\
\hline Citrate & - & + & + \\
\hline Glucose & - & + & + \\
\hline Fructose & - & + & + \\
\hline Galactose & - & - & + \\
\hline Glycerol & - & - & + \\
\hline Glycine & - & ND & + \\
\hline Glutamic acid & - & + & + \\
\hline Casamino acids $(0 \cdot 2 \%)$ & +++ & + & + \\
\hline Yeast extract $(0.5 \%)$ & +++ & + & + \\
\hline Marine broth (Difco 2217) & +++ & +++ & +++ \\
\hline
\end{tabular}

* Except for marine broth, data as reported by Lafay et al. (1995); data reported only as + or - .

$\dagger$ Except for marine broth, as reported by Ruiz-Ponte et al. (1998); data reported only as + or - .

$0.37 \mathrm{mM})$, MeI $\left(0.04 \mathrm{~h}^{-1}, 0.13 \mathrm{mM}\right)$ and DMS $\left(0.01 \mathrm{~h}^{-1}, 0.05 \mathrm{mM}\right)$. Glycine betaine supported growth at $1 \mathrm{mM}$, but not at $5 \mathrm{mM}$. Growth was also observed on the following complex substrates: Casamino acids, yeast extract and marine broth (Table 1). These complex substrates each contained one or more of the defined substrates shown to support growth, although additional growth substrates may have been present. For example, Casamino acids and yeast extract both contain methionine, and yeast extract contains $1-3 \%(\mathrm{w} / \mathrm{w})$ glycine betaine (Farrell et al., 1993; Oren, 1999; Jansen \& Hansen, 2001). Growth on $1 \mathrm{mM}$ glycine betaine could be monitored by $\mathrm{OD}_{680}$ (versus by AODC), although readings were low $(0 \cdot 1)$ compared to growth on yeast extract $(0 \cdot 9)$.

Strain $\mathrm{MB}^{\mathrm{T}}$ was an obligate aerobe, being unable to grow in the absence of oxygen on yeast extract with or without nitrate (data not shown). In addition to the compounds given in Table 1, no growth was observed on the following substrates: no added carbon, as- paragine $(5 \mathrm{mM})$, cysteine $(4 \mathrm{mM})$, dimethylamine $(5$ or $0.05 \mathrm{mM})$, formate $(5 \mathrm{mM})$, glutamine $(2.5 \mathrm{mM})$, homocysteine $(5 \mathrm{mM})$, methanesulfonic acid (5 or $0.05 \mathrm{mM})$, monomethylamine $(5 \mathrm{mM})$, serine $(5 \mathrm{mM})$, threonine $(5 \mathrm{mM})$, trimethylamine $(5$ or $0.05 \mathrm{mM})$ or urea $(5 \mathrm{mM})$. Furthermore, no growth was observed on a mixture of L-amino acids that included $(0 \cdot 1 \%$, $\mathrm{w} / \mathrm{v}$, each) arginine, cysteine, glutamate, glycine, phenylalanine, serine and tyrosine.

Strain $\mathrm{MB}^{\mathrm{T}}$ demonstrated exponential growth on $\mathrm{MeBr}$ (Fig. 2), $\mathrm{MeCl}, \mathrm{MeI}$ and methionine. Lag periods were not observed for methionine or $\mathrm{MeBr}$ consumption, but did occur with $\mathrm{MeCl}$ and $\mathrm{MeI}$ (data not shown). Experiments with radiolabelled $\mathrm{MeBr}$ demonstrated that strain $\mathrm{MB} 2{ }^{\mathrm{T}}$ oxidized ${ }^{14} \mathrm{C}-\mathrm{MeBr}$ to ${ }^{14} \mathrm{CO}_{2}(18 \%$ in $2 \mathrm{~h})$, whereas no ${ }^{14} \mathrm{CO}_{2}$ was detected in sterile controls. When strain $\mathrm{MB}^{\mathrm{T}}$ was grown with $\mathrm{MeBr}$ and MeI, it was necessary to add these substrates as discrete pulses over the course of the incubation to prevent toxicity (Connell Hancock et al., 1998; Miller 


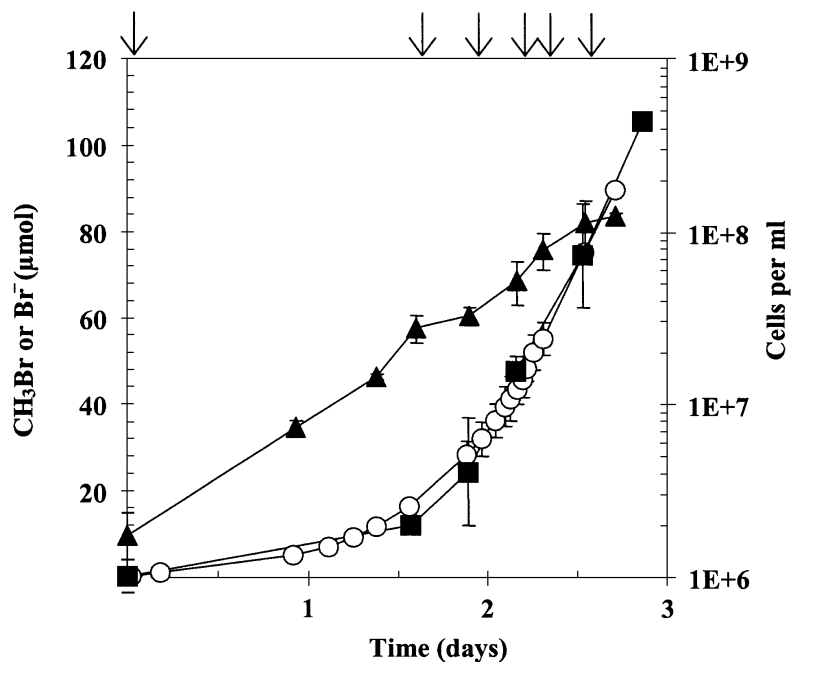

Fig. 2. Growth of strain $M B 2^{\top}$ on $M e B r . ~ \bigcirc, M e B r$ consumption; $\boldsymbol{\square}$, bromide release; $\boldsymbol{\Delta}$, cells per $\mathrm{ml}$. No growth was observed without $\mathrm{MeBr}$ (not shown). Arrows indicate pulsed additions of $\mathrm{MeBr}$. Symbols represent the mean of three cultures; bars, \pm 1 SD.

et al., 1997). Pulsed additions were not required for methionine or $\mathrm{MeCl}$, presumably because of the lower reactivity of these compounds.

In contrast to other substrates, growth on DMS $(0.5$ or $0.05 \mathrm{mM}$ ) ceased after about $\sim 50 \mathrm{~h}$ whether or not pulsed additions were used (data not shown), raising the possibility that strain $\mathrm{MB} 2^{\mathrm{T}}$ could not be maintained on DMS. Although growth was limited, a cellline was maintained on $0.05 \mathrm{mM}$ DMS through three sequential transfers. After each transfer, cell densities increased $\sim 10$-fold in $72 \mathrm{~h}$, typically reaching a maximum of $\sim 2 \times 10^{5}$ cells $\mathrm{ml}^{-1}$. For comparison, cells grown on $\mathrm{MeBr}$ or methionine increased $>100-$ fold in $48 \mathrm{~h}$, reaching densities of $10^{7}-10^{8}$ cells $\mathrm{ml}^{-1}$. No growth was observed on 1.4 or $5 \mathrm{mM}$ DMS.

$\mathrm{MB}^{\mathrm{T}}$ is a methylotroph because it grows on methyl halides ( $\mathrm{MeBr}, \mathrm{MeCl}, \mathrm{MeI})$ and to a limited extent on DMS. Curiously, no growth was noted with any other $\mathrm{C}_{1}$ substrate, including methylated amines, methanol and formate. The original enrichment culture from which strain $\mathrm{MB}^{\mathrm{T}}$ was isolated did not grow on methane (Goodwin et al., 1998) and it was unable to degrade methyl fluoride or dibromomethane (K. Goodwin and J. K. Schaefer, unpublished results). Although the mixed culture could utilize methylated amines (Goodwin et al., 1998), strain MB2 ${ }^{\mathrm{T}}$ could not. In this respect, strain $\mathrm{MB}^{\mathrm{T}}$ differed markedly from the facultative methylotrophs, strains IMB-1 and CC495, which grow on methylated amines in addition to methyl halides (Connell Hancock et al., 1998; Coulter et al., 1999).

Strain $\mathrm{MB}^{\mathrm{T}}$ grew on glycine betaine and methionine, which would seem to suggest that it is a facultative rather than an obligate methylotroph. However, the inability of strain $\mathrm{MB}^{\mathrm{T}}$ to grow on demethylated analogues such as homocysteine, glycine and cysteine suggests that growth on glycine betaine and methionine occurred at the expense of their methyl groups. Therefore, strain $\mathrm{MB}^{\mathrm{T}}$ appears to be an obligate methylotroph, capable of growth on a limited suite of substrates that include methyl halides, DMS and some compounds having $\mathrm{C}_{1}$ units attached as methyl groups to $\mathrm{S}$ or $\mathrm{N}$ atoms.

\section{Methyl halide degradation}

A 1:1 stoichiometry between $\mathrm{MeBr}$ oxidation and the accumulation of $\mathrm{Br}^{-}$in the medium was observed (Fig. $2)$. There was negligible $\mathrm{MeBr}$ loss $(\sim 2.6 \%)$ in sterile controls (data not shown) attributable to chemical hydrolysis and halide exchange (Elliott \& Rowland, 1993). A similar relationship was observed between MeI oxidation and the accumulation of $\mathrm{I}^{-}$in the medium. After 3 days incubation, cells had consumed $10 \mu \mathrm{mol} \mathrm{MeI}$, whereas $12 \mu \mathrm{mol} \mathrm{\textrm {I } ^ { - }}$ was detected in the medium. After 7 days incubation, the amount of $\mathrm{I}^{-}$ recovered increased to $22 \mu \mathrm{mol}$, which agreed with the $19 \mu \mathrm{mol} \mathrm{MeI} \mathrm{consumed.} \mathrm{The} \mathrm{abiotic} \mathrm{loss} \mathrm{of} \mathrm{MeI} \mathrm{that}$ occurred in controls $(\sim 16 \%$ of initial level) was insignificant compared to the consumption in live samples. Accumulations of $\mathrm{Cl}^{-}$during $\mathrm{MeCl}$ oxidation could not be followed because of the high background levels of this ion in the marine medium. No significant loss of $\mathrm{MeCl}(<1 \%)$ occurred in sterile controls (data not shown).

After $\sim 19 \mathrm{~h}$ incubation in the presence of 80 or $420 \mu \mathrm{M} \mathrm{MeBr}$, suspensions of Casamino acid-grown cells demonstrated $\mathrm{MeBr}$ consumption, whereas suspensions incubated with chloramphenicol were unable to oxidize $\mathrm{MeBr}$ (data not shown), indicating that the enzyme(s) for $\mathrm{MeBr}$ degradation required induction. Methyl halide degradation was also found to require induction in Methylobacterium $\mathrm{CM}_{4}{ }^{\mathrm{T}}$ (Vannelli et al., 1998) and strain CC495 (Coulter et al., 1999). Oxidation of high levels $(>100 \mu \mathrm{M})$ of $\mathrm{MeBr}$ required induction in strain IMB-1, although there appeared to be a constitutive ability to consume low levels of $\mathrm{MeBr}$ (18 nM) (Schaefer \& Oremland, 1999). Therefore, the pathway of methyl halide degradation does not appear to be constitutive amongst methyl halide-degrading bacteria, at least at high concentrations.

\section{Physiological characteristics}

Strain $\mathrm{MB}^{\mathrm{T}}$ was isolated from seawater and is clearly a marine bacterium. Growth occurred over a salinity range of $10-60 \mathrm{~g} \mathrm{NaCl} \mathrm{l}^{-1}$, with an optimum at the salinity of seawater (Fig. 3a). In contrast, strain IMB1 , a terrestrial organism, had an optimum at $\sim 2 \mathrm{~g}^{-1}$ and did not grow at $>10 \mathrm{~g} \mathrm{l}^{-1}$. The optimum $\mathrm{Mg}^{2+}$ concentration for strain MB2 ${ }^{\mathrm{T}}$ was $40-80 \mathrm{mM}$, which overlaps with the $54 \mathrm{mM}$ concentration found in seawater (data not shown). Strain $\mathrm{MB}^{\mathrm{T}}$ had a lower 

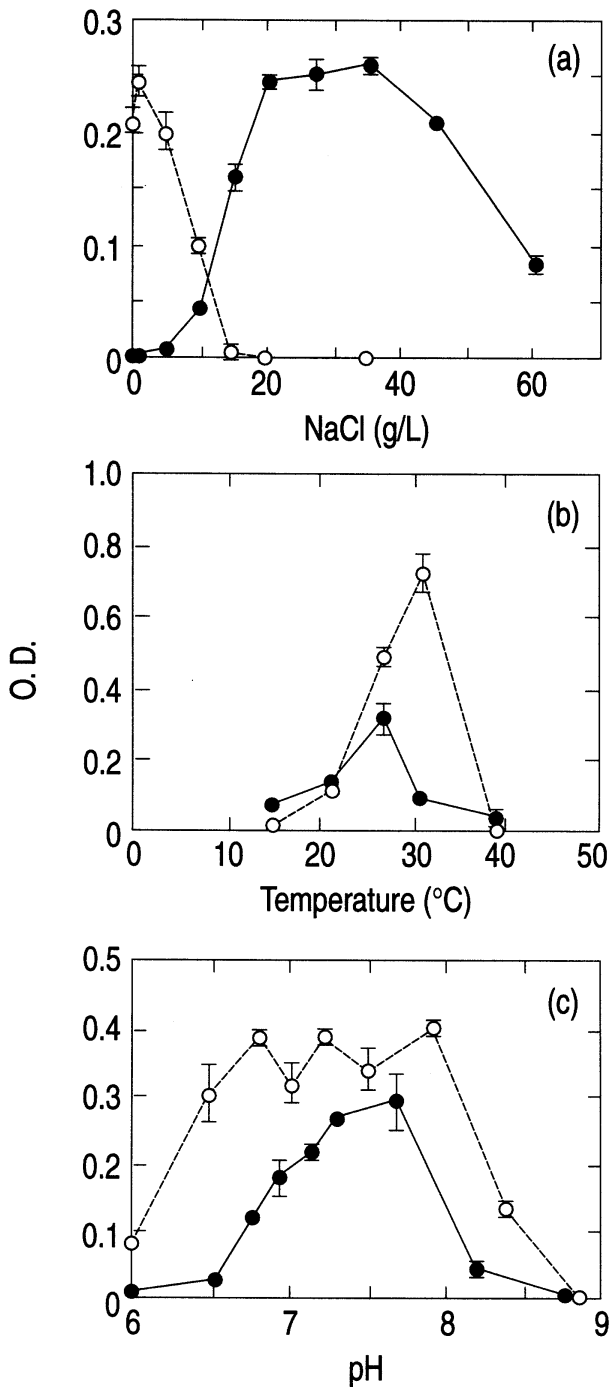

Fig. 3. Effect of salinity (a), temperature (b) and $\mathrm{pH}$ (c) on growth of strain $\mathrm{MB}^{\top}(\mathbf{0})$ and strain IMB-1 $(O)$, grown on $0.2 \%$ yeast extract and $10 \mathrm{mM}$ glucose, respectively. $O_{680}$ measurements were taken at same time for all conditions. Symbols represent the mean of three cultures; bars, \pm 1 SD.

optimum temperature for growth than strain IMB-1 (Fig. 3b). The lack of growth above $\mathrm{pH} 8$ (Fig. 3c) was most likely due to precipitation of the magnesium and calcium salts, rather than a response to a physiological constraint of $\mathrm{pH}$. Other characteristics of strain $\mathrm{MB}^{\mathrm{T}}$ are given in Table 1.

\section{$\mathbf{G}+\mathbf{C}$ content and DNA-DNA hybridization}

The $\mathrm{G}+\mathrm{C}$ content of Leisingera methylohalidivorans $\mathrm{MB} 2^{\mathrm{T}}$ was determined to be $60 \cdot 5 \pm 0 \cdot 2 \mathrm{~mol} \%$, which is similar to that reported for DNA from Ruegeria algicola and Roseobacter gallaeciensis (Table 1). Since the $\mathrm{G}+\mathrm{C}$ contents of DNA from these strains were so similar, hybridization of DNA from strain $\mathrm{MB}^{\mathrm{T}}$ to DNA from Ruegeria algicola $\mathrm{FF}^{\mathrm{T}}$ and Roseobacter gallaeciensis $\mathrm{BS} 107^{\mathrm{T}}$ were performed. Unlabelled
DNA from salmon sperm, Ruegeria algicola or Roseobacter gallaeciensis was allowed to hybridize with labelled DNA from strain MB2 ${ }^{\mathrm{T}}$ resulting in duplex products with mean counts of 2893, 2721 and 2999 d.p.m. per filter, respectively. In contrast, DNA from strain $\mathrm{MB} 2^{\mathrm{T}}$ hybridized to itself resulted in a final duplex with counts of 50025 c.p.m. per filter. Therefore, DNA from strain MB2 ${ }^{\mathrm{T}}$ had very low $(<1 \%)$ hybridization to DNA from either Ruegeria algicola or Roseobacter gallaeciensis.

\section{$16 S$ rRNA sequence analysis}

Phylogenetic analysis of the 16S rDNA sequence of strain $\mathrm{MB}^{\mathrm{T}}$ grouped this bacterium with species in proximity to the Ruegeria and Roseobacter genera, being most closely related to Roseobacter gallaeciensis, Ruegeria algicola and strain GAI-5, a facultative methylotroph isolated from coastal seawater (González \& Moran, 1997) (Fig. 4). The 16S rDNA sequences obtained from two separate clones of $\mathrm{MB}^{\mathrm{T}}$ were identical. Analysis with DNAML and DNAPARS produced identical phylogenies to those produced by DNADIST. The $16 \mathrm{~S}$ rDNA sequence of MB2 ${ }^{\mathrm{T}}$ had closest identity to those from Ruegeria algicola $(97 \cdot 5 \%)$ and Roseobacter gallaeciensis $(97 \cdot 1 \%)$.

Strain $\mathrm{MB}^{\mathrm{T}}$ was distinct from Roseobacter denitrificans and Roseobacter litoralis, which are pinkpigmented bacteria that contain bacteriochlorophyll $a$ (Shiba, 1991). Roseobacter was originally defined as the genus containing these aerobic photosynthetic species, and the lack of bacteriochlorophyll $a$ was a primary motivation for reclassifying Roseobacter algicola as Ruegeria algicola (Uchino et al., 1998; Trüper \& Imhoff, 1999). Yurkov \& Beatty (1998) also called for reclassification on these grounds. Moreover, work to differentiate Roseobacter-related bacteria using $16 \mathrm{~S}-23 \mathrm{~S}$ internal transcribed spacer sequences confirms a clear separation of Ruegeria algicola from Roseobacter denitrificans and Roseobacter litoralis (Söller et al., 2000). Strain MB2 ${ }^{\mathrm{T}}$ is unpigmented and lacks bacteriochlorophyll $a$, and therefore lacks the main distinguishing feature of the genus Roseobacter. Furthermore, it is noted that Roseobacter gallaeciensis (Ruiz-Ponte et al., 1998), Roseobacter sp. DSS8 and Roseobacter sp. GA15 also lack bacteriochlorophyll $a$, suggesting that the placement of those organisms in the Roseobacter genus should be re-examined. In addition, phylogenetic analysis (Fig. 4) indicates that there are at least two groups of Ruegeria species, the first comprising Ruegeria atlantica, Ruegeria gelatinovorans and Roseobacter sp. DSS8. The second group comprises Ruegeria algicola, which groups with Roseobacter gallaeciensis, and Roseobacter sp. GA15. In the future, the phylogeny of these bacteria should be clarified.

Strain $\mathrm{MB} 2^{\mathrm{T}}$ had a similar $\mathrm{G}+\mathrm{C}$ content to Roseobacter gallaeciensis and Ruegeria algicola (Table 1) and was related to these bacteria as indicated by $16 \mathrm{~S}$ rDNA sequences (Fig. 4). However, DNA-DNA hybrid- 


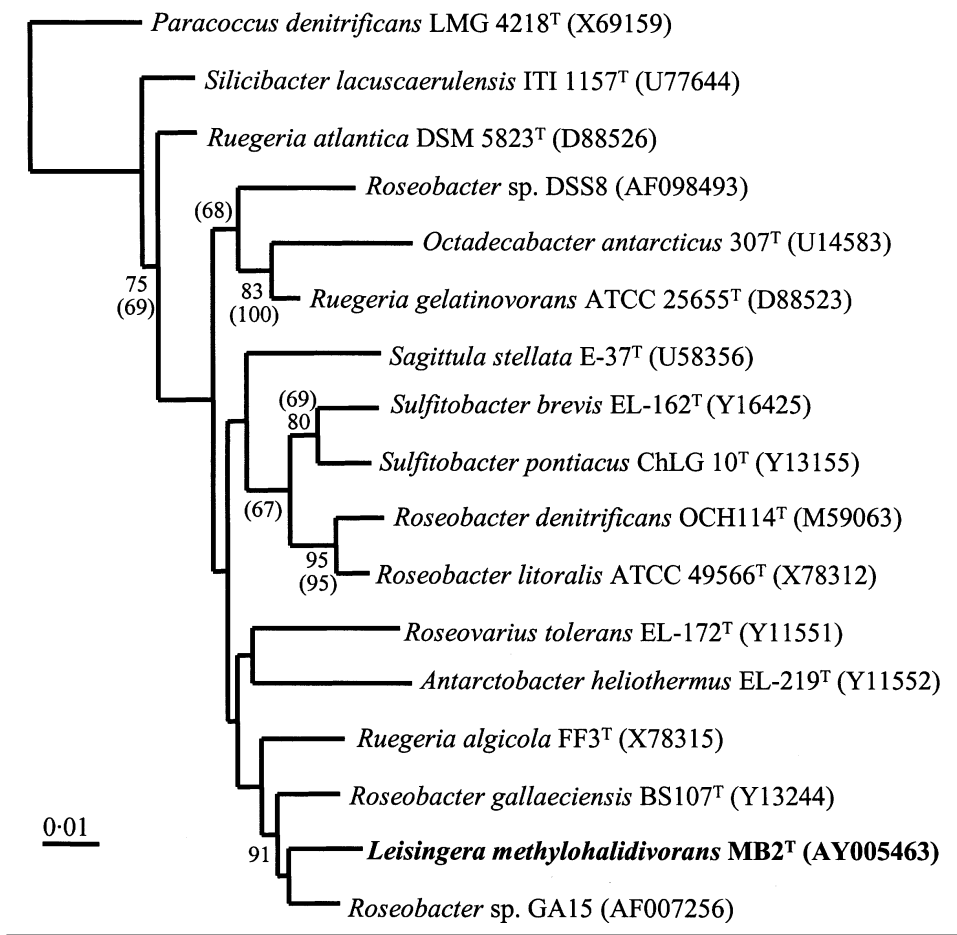

Fig. 4. Phylogenetic analysis of the $16 \mathrm{~S}$ rRNA sequence of strain $M B 2^{\top}$. The dendrogram shows the results of DNADIST analysis, based on the comparison of $1126 \mathrm{nt}$. Bootstrap values greater than $65 \%$ derived from 100 replicates are also shown (DNADIST values; DNAPARS values given in parentheses). Bar, 0.01 Jukes-Cantor substitutions per nucleotide. ization results showed a very low level of hybridization to either Ruegeria algicola or Roseobacter gallaeciensis. Based on this lack of hybridization and the lack of pigmentation, it is proposed that strain $\mathrm{MB}^{\mathrm{T}}$ be designated a new species in a new genus, Leisingera methylohalidivorans gen. nov., sp. nov.

\section{Comparison of Leisingera methylohalidivorans $\mathrm{MB2}^{\top}$ to members of the genera Roseobacter and Ruegeria}

Phylogenetic neighbours of L. methylohalidivorans $\mathrm{MB}^{\mathrm{T}}$ were tested for their ability to degrade $\mathrm{MeBr}$ in order to assess whether methyl halide degradation was also a general ability of the Roseobacter/Ruegeria genera. Neither Roseobacter gallaeciensis $\mathrm{BS} 107^{\mathrm{T}}$ nor Ruegeria algicola $\mathrm{FF}^{\mathrm{T}}$ was able to consume $\mathrm{MeBr}$, even at concentrations as low as $8.5 \mu \mathrm{M}$. Ruegeria algicola was also tested using $200 \mu \mathrm{M} \mathrm{MeBr}$, a concentration routinely used to grow strain $\mathrm{MB}^{\mathrm{T}}$, but this amount of $\mathrm{MeBr}$ appeared to kill the culture. Furthermore, Roseobacter group strains GAI-37 and DSS-3 (González et al., 1999) were unable to consume $\mathrm{MeBr}$ (data not shown).

Many bacteria in the genera Roseobacter and Ruegeria can utilize a wide variety of substrates, including glucose and acetate (González et al., 1999; Lafay et al., 1995; Ruiz-Ponte et al., 1998), whereas strain MB2 ${ }^{\mathrm{T}}$ exhibited a narrower substrate range. Two other nonpigmented isolates, namely Roseobacter sp. GA15 (González \& Moran, 1997) and Roseobacter sp. DSS8 (González et al., 1999), can oxidize DMS to DMSO, but it is not known if this reaction supports growth (J. M. Gonzalez, personal communication). Niches for $\mathrm{MeBr}$-oxidizing bacteria could perhaps be found near
MeBr-producing phytoplankton (Saemundsdóttir \& Matrai, 1998; Scarratt \& Moore, 1998) or in shallow coastal waters that contain large macroalgal communities that produce methyl halides (Goodwin et al., 1998; Manley \& Dastoor, 1987).

\section{Description of Leisingera gen. nov.}

Leisingera (Lei.sin'ge.ra. N.L. fem. n. Leisingera in honour of Thomas Leisinger, on the occasion of his retirement and for his contributions to our understanding of the biochemistry of bacterial methyl halide metabolism).

Obligatory aerobic, moderately halophilic rods. Gram-negative reaction. Grows by oxidation of methyl halides, or select methylated substrates like methionine. The $\mathrm{G}+\mathrm{C}$ content of the only strain isolated thus far is $60.5 \mathrm{~mol} \%$. Found in coastal marine tide pools. Type species is Leisingera methylohalidivorans.

\section{Description of Leisingera methylohalidivorans sp. nov.}

Leisingera methylohalidivorans (me.thy.lo.ha.li.di. vo'rans. N.L. n. methylohalidium methyl halide; L. part. pres. vorans devouring; methylohalidivorans degrading methyl halides).

Cells are motile, Gram-negative rods which occur singly or in pairs $(1.1-1.4 \times 0.4-0.5 \mu \mathrm{m})$ when grown on methyl halides, methionine or DMS. Cells demonstrate pleomorphism when grown on yeast extract or glycine betaine, becoming enlarged and elongated $(2-10 \mu \mathrm{m}$ in length). Colonies are non-pigmented, 
smooth, with an entire edge when grown on solid media regardless of carbon source. When grown on methyl bromide on solid media, colony diameter is $<1 \mathrm{~mm}$; however, when grown on solid media with yeast extract or marine agar, the diameter is $\sim 2-3 \mathrm{~mm} . \mathrm{pH}$ and temperature optima are 7.7 and $27^{\circ} \mathrm{C}$, respectively. Unable to grow at $\mathrm{NaCl}$ concentrations of $<10 \mathrm{~g}^{-1}$. Cells have a fairly narrow substrate range being restricted to a limited number of methylotrophic substrates such as methyl halides, DMS, and the methyl groups of methionine and glycine betaine. Growth also occurs on complex substrates such as yeast extract, Casamino acids and marine broth. Simple carbohydrates, amino acids (other than methionine) and small organic acids cannot serve as sole sources of carbon and energy. Catalase- and oxidase-positive. Does not hydrolyse starch. Unable to use nitrate as an electron acceptor. Does not require vitamins for growth. Inhibited by penicillin $\mathrm{G}$. $\mathrm{G}+\mathrm{C}$ content is $60 \cdot 5 \pm 0 \cdot 2 \mathrm{~mol} \%$. Type strain is Leisingera methylohalidivorans $\mathrm{MB}^{\mathrm{T}}$ (= ATCC BAA-92 ${ }^{\mathrm{T}}=$ DSM $14336^{\mathrm{T}}$ ).

\section{ACKNOWLEDGEMENTS}

We thank M. Häggblom and T. Barkay for the use of materials and lab space, A. Whiteside for technical assistance, A. Sardeshmukh and Jodi Switzer Blum for laboratory assistance, M. A. Moran for Roseobacter group strains and $\mathrm{H}$. Trüper for help with the epithet. This research was supported by NASA-Upper Atmospheric Research Program grant 5188-AU-0080 to the USGS and by cooperative agreement NA67RJ0-149 of CIMAS (University of Miami and NOAA).

\section{REFERENCES}

Connell, T. L., Joye, S. B., Miller, L. G. \& Oremland, R. S. (1997). Bacterial oxidation of methyl bromide in Mono Lake, California. Environ Sci Technol 31, 1489-1495.

Connell Hancock, T. L., Costello, A. M., Lidstrom, M. E. \& Oremland, R. S. (1998). Strain IMB-1, a novel bacterium for the removal of methyl bromide in fumigated agricultural soils. Appl Environ Microbiol 64, 2899-2905.

Coulter, C., Hamilton, J.T. G., McRoberts, W. C., Kulakov, L., Larkin, M. J. \& Harper, D. B. (1999). Halomethane: bisulfide/halide ion methyltransferase, an unusual corrinoid enzyme of environmental significance isolated from an aerobic methylotroph using chloromethane as the sole carbon source. Appl Environ Microbiol 65, 4301-4312.

Culbertson, C. W., Zehnder, A. J. B. \& Oremland, R. S. (1981). Anaerobic oxidation of acetylene by estuarine sediments and enrichment cultures. Appl Environ Microbiol 41, 396-403.

DeBruyn, W. J. \& Saltzman, E. S. (1997). The solubility of methyl bromide in pure water, $35 \%$ sodium chloride and seawater. Mar Chem 56, 51-57.

Doronina, N. V. \& Trotsenko, Y. A. (1997). Isolation and characterization of aerobic degraders of methyl chloride. Mikrobiologiya $\mathbf{6 6}$, $57-64$.

Duddleston, K. N., Bottomley, P. J., Porter, A. J. \& Arp, D. J. (2000). New insights into methyl bromide cooxidation by Nitrosomonas europaea obtained by experimenting with moderately low density cell suspensions. Appl Environ Microbiol 66, 2726-2731.

Elliott, S. \& Rowland, S. (1993). Nucleophilic substitution rates and solubilities for methyl halides in seawater. Geophys Res Lett 20, 1043-1046.
Farrell, R. E., Germida, J. J. \& Huang, P. M. (1993). Effects of chemical speciation in growth media on the toxicity of mercury(II). Appl Environ Microbiol 59, 1507-1514.

Felsenstein, J. (1993). PHYLIP (phylogenetic inference package) version 3.5c. Department of Genetics, University of Washington, Seattle, USA.

Goodwin, K. D., Schaefer, J. K. \& Oremland, R. S. (1998). Bacterial oxidation of dibromomethane and methyl bromide in natural waters and enrichment cultures. Appl Environ Microbiol 64, 4629-4636.

González, J. M. \& Moran, M. A. (1997). Numerical dominance of a group of marine bacteria in the $\alpha$-subclass of the class Proteobacteria in coastal seawater. Appl Environ Microbiol 63, 4237-4242.

González, J. M., Kiene, R. P. \& Moran, M. A. (1999). Transformation of sulfur compounds by an abundant lineage of marine bacteria in the $\alpha$-subclass of the class Proteobacteria. Appl Environ Microbiol 65, 3810-3819.

Hines, M. E., Crill, P. M., Varner, R. K., Talbot, R. W., Shorter, J. H., Kolb, C. E. \& Harriss, R. C. (1998). Rapid consumption of low concentrations of methyl bromide by soil bacteria. Appl Environ Microbiol 64, 1864-1870.

Hobbie, J. E., Daley, R. J. \& Jasper, S. (1977). Use of Nucleopore filters for counting bacteria by fluorescence microscopy. Appl Environ Microbiol 33, 1225-1228.

Hoeft, S. E., Rogers, D. R. \& Visscher, P. T. (2000). Metabolism of methyl bromide and dimethyl sulfide by marine bacteria isolated from coastal and open waters. Aquat Microbiol Ecol 21, 221-230.

Hunter-Smith, R. J., Balls, P. W. \& Liss, P. S. (1983). Henry's Law constants and the air-sea exchange of various low molecular weight halocarbon gases. Tellus 35B, 170-176.

Jansen, M. \& Hansen, T. A. (2001). Non-growth-associated demethylation of dimethylsulfoniopropionate by (homo)acetogenic bacteria. Appl Environ Microbiol 67, 300-306.

Johnson, J. L. (1994). Similarity analysis of DNAs. In Methods for General and Molecular Bacteriology, pp. 655-682. Edited by P. Gerhardt, R. G. E. Murray, W. A. Wood \& N. R. Krieg. Washington, DC: American Society for Microbiology.

Keener, W. K. \& Arp, D. J. (1993). Kinetic studies of ammonia monooxygenase inhibition in Nitrosomonas europaea by hydrocarbons and halogenated hydrocarbons in an optimized whole-cell assay. Appl Environ Microbiol 59, 2501-2510.

King, D. B. \& Saltzman, E. S. (1997). Removal of methyl bromide in coastal seawater: chemical and biological rates. J Geophys Res 102, 18715-18721.

Lafay, B., Ruimy, R., Rausch de Traubenberg, C., Breittmayer, V., Gauthier, M. J. \& Christen, R. (1995). Roseobacter algicola sp. nov., a new marine bacterium isolated from the phycosphere of the toxinproducing dinoflagellate Prorocentrum lima. Int J Syst Bacteriol 45, 290-296.

Lane, D. J. (1991). 16S/23S rRNA sequencing. In Nucleic Acid Techniques in Bacterial Systematics, pp. 115-175. Edited by E. Stackebrandt \& M. Goodfellow. Chichester: John Wiley.

McDonald, I. R., Doronina, N. V., Trotsenko, Y. A., McAnulla, C. \& Murrell, J. C. (2001). Hyphomicrobium chloromethanicum sp. nov. and Methylobacterium chloromethanicum sp. nov., chloromethane-utilizing bacteria isolated from a polluted environment. Int J Syst Evol Microbiol 51, 119-122.

Manley, S. L. \& Dastoor, M. N. (1987). Methyl halide $\left(\mathrm{CH}_{3} \mathrm{X}\right)$ production from giant kelp. Limnol Oceanogr 32, 709-715.

Marmur, J. (1961). A procedure for the isolation of deoxyribonucleic acid from microorganisms. $J$ Mol Biol 3, 208-218.

Mellouki, A., Talukar, R. K., Schmoltner, A.-M., Gierzak, T., Mills, M. J., Solomon, S. \& Ravishankara, A. R. (1992). Atmospheric lifetimes and ozone depletion potentials of methyl bromide $\left(\mathrm{CH}_{3} \mathrm{Br}\right)$ and dibromomethane $\left(\mathrm{CH}_{2} \mathrm{Br}_{2}\right)$. Geophys Res Lett 19, 2059-2062.

Miller, L. G., Connell, T. L., Guidetti, J. R. \& Oremland, R. S. (1997). Bacterial oxidation of methyl bromide in fumigated agricultural fields. Appl Environ Microbiol 63, 4346-4354.

Oremland, R. S., Miller, L. G., Culbertson, C. W., Connell, T. L. \& 
Jahnke, L. (1994). Degradation of methyl bromide by methanotrophic bacteria in cell suspensions and soils. Appl Environ Microbiol 60, $3640-3646$

Oren, A. (1999). Bioenergetic aspects of halophilism. Microbiol Mol Biol Rev 63, 334-348.

Page, R. D. M. (1996). TREEVIEW: an application to display phylogenetic trees on personal computers. Comput Appl Biosci 12, 357-358.

Pfennig, N. (1978). Rhodocyclus purpureus gen. nov. and sp. nov., a ring-shaped, vitamin $\mathrm{B}_{12}$-requiring member of the family Rhodospirillaceae. Int J Syst Bacteriol 28, 283-288.

Ruiz-Ponte, C., Cilia, V., Lambert, C. \& Nicolas, J. L. (1998). Roseobacter gallaeciensis sp. nov., a new marine bacterium isolated from rearings and collectors of the scallop Pecten maximus. Int J Syst Bacteriol 48, 537-542.

Saemundsdóttir, S. \& Matrai, P. A. (1998). Biological production of methyl bromide by cultures of marine phytoplankton. Limnol Oceanogr 43, 81-87.

Saunders, S. E. \& Burke, J. F. (1990). Rapid isolation of miniprep DNA for double strand sequencing. Nucleic Acids Res 18, 4948.

Scarratt, M. G. \& Moore, R. M. (1998). Production of methyl bromide and methyl chloride in laboratory cultures of marine phytoplankton II. Mar Chem 59, 311-320.

Schaefer, J. K. \& Oremland, R. S. (1999). Oxidation of methyl halides by the facultative methylotroph strain IMB-1. Appl Environ Microbiol 65, 5035-5041.

Schauffler, S. M., Atlas, E. L., Flocke, F., Lueb, R. A., Stroud, V. \& Travnicek, W. (1998). Measurements of bromine containing organic compounds at the tropical tropopause. Geophys Res Lett 25, 317-320.

Shiba, T. (1991). Roseobacter litoralis gen. nov., sp. nov., and Roseobacter denitrificans sp. nov., aerobic pink-pigmented bacteria which contain bacteriochlorophyll a. Syst Appl Microbiol 14, 140-145.

Smith, R. L., Strohmaier, F. E. \& Oremland, R. S. (1985). Isolation of anaerobic oxalate degrading bacteria from freshwater lake sediments. Arch Microbiol 141, 8-13.

Söller, R., Hirsch, P., Blohm, D. \& Labrenz, M. (2000). Differentiation of newly described Antarctic bacterial isolates related to Roseobacter species based on 16S-23S rDNA internal transcribed spacer sequences. Int J Syst Evol Microbiol 50, 909-915.
Strunk, O. Gross, O. Reichel, B. \& 10 other authors (2000). ARB: a software environment for sequence data (http://www.mikrobiologie. tu-muenchen.de). Department of Microbiology, Technische Universität München, Munich, Germany.

Thompson, A. S., Owens, N. J. P. \& Murrell, J. C. (1995). Isolation and characterization of methanesulfonic acid-degrading bacteria from the marine environment. Appl Environ Microbiol 61, 2388-2393.

Tokarczyk, R. \& Saltzman, E. S. (2001). Methyl bromide loss rates in surface waters of the North Atlantic Ocean, Caribbean Sea, and Eastern Pacific Ocean (8-45N). J Geophys Res 106, 9843-9851.

Trüper, H. G. \& Imhoff, J. F. (1999). International Committee on Systematic Bacteriology Subcommittee on the taxonomy of phototrophic bacteria. Int J Syst Bacteriol 49, 925-926.

Uchino, Y., Hirata, A., Yokota, A. \& Sugiyama, J. (1998). Reclassification of marine Agrobacterium species: proposals of Stappia stellulata gen. nov., comb. nov., Stappia aggregata sp. nov., nom. rev., Ruegeria atlantica gen. nov., comb. nov., Ruegeria gelatinovora comb. nov., Ruegeria algicola comb. nov., and Ahrensia kieliense gen. nov., sp. nov., nom. rev. J Gen Appl Microbiol 44, 201-210.

Vannelli, T., Studer, A., Kertesz, M. \& Leisinger, T. (1998). Chloromethane metabolism by Methylobacterium sp. strain CM4. Appl Environ Microbiol 64, 1933-1936.

Varner, R. K., Crill, P. M., Talbot, R. W. \& Shorter, J. H. (1999). An estimate of the uptake of atmospheric methyl bromide by agricultural soils. Geophys Res Lett 26, 727-730.

Widdel, F., Kohring, G.-W. \& Mayer, F. (1983). Studies on the dissimilatory sulfate-reducing bacteria that decompose fatty acids. III. Characterization of the filamentous gliding Desulfonema limicola gen. nov., sp. nov., and Desulfonema magnum sp. nov. Arch Microbiol 134, 286-294.

Yurkov, V. V. \& Beatty, J. T. (1998). Aerobic anoxygenic phototrophic bacteria. Microbiol Mol Biol Rev 62, 695-724.

Yvon, S. A. \& Butler, J.H. (1996). An improved estimate of the oceanic lifetime of atmospheric $\mathrm{CH}_{3} \mathrm{Br}$. Geophys Res Lett 23, 53-56.

Yvon-Lewis, S. A. \& Butler, J.H. (1997). The potential effect of oceanic biological degradation on the lifetime of atmospheric $\mathrm{CH}_{3} \mathrm{Br}$. Geophys Res Lett 24, 1227-1230. 